Rural Disadvantage in Georgian Higher Education Admissions: A Mixed-Methods Study

Author(s): Maia Chankseliani

Source: Comparative Education Review, Vol. 57, No. 3, Special Issue on Fair Access to Higher

Education (August 2013), pp. 424-456

Published by: The University of Chicago Press on behalf of the Comparative and International

Education Society

Stable URL: http://www.jstor.org/stable/10.1086/670739

Accessed: 26/06/2014 05:23

Your use of the JSTOR archive indicates your acceptance of the Terms \& Conditions of Use, available at http://www.jstor.org/page/info/about/policies/terms.jsp

JSTOR is a not-for-profit service that helps scholars, researchers, and students discover, use, and build upon a wide range of content in a trusted digital archive. We use information technology and tools to increase productivity and facilitate new forms of scholarship. For more information about JSTOR, please contact support@ jstor.org. 


\title{
Rural Disadvantage in Georgian Higher Education Admissions: A Mixed-Methods Study
}

\author{
MAIA CHANKSELIANI
}

\begin{abstract}
The study investigates the chances of gaining admission to Georgian higher education in relation to residential origin. The analysis of broad trends is combined with details from an in-depth individual-level inquiry. Quantitative data on the entire population of 150,000 applicants over the period 2005-9, together with interview data from a purposive sample of families and policy makers, are examined. Findings indicate that urban applicants consistently score higher on university entrance exams compared to rural applicants, and their odds of gaining university admission are 1.22 times higher. Among those with the same measured aptitude, rural applicants are 12 times more likely to apply to one of the least prestigious higher education institutions than are applicants from urban areas.
\end{abstract}

\section{Introduction}

Spatial inequalities in educational achievement and attainment are currently underresearched. ${ }^{1}$ In studies of educational outcomes, location effects often are treated as a residual category that remain unexplained after researchers have controlled for an array of individual-, school-, and family-level characteristics. In the absence of a robust literature, our knowledge of spatial inequalities is confined to studies that try to disentangle family and school effects from area effects. Whereas influences of an individual's family are considered to be much larger, area effects are also recognized as contributing to educational outcomes. ${ }^{2}$ As such, geographical differences may be an important aspect of stratification related to educational outcomes, and warrant further investigation.

A pioneering interest in area effects as related to social structures and, specifically, education appeared in the late 1970s, when sociologist Philip

\footnotetext{
${ }^{1}$ See, e.g., Brasington (2002), Hannum and Wang (2006), Roscigno et al. (2006), and Zhang and Cowen (2009).

${ }^{2}$ See, e.g., Datcher (1982), Crane (1991), Garner and Raudenbush (1991), Duncan (1994), Leventhal and Brooks-Gunn (2000), Ainsworth (2002), Rankin and Quane (2002), Rephann (2002), Andersson (2004), Andersson and Subramanian (2006), Sastry et al. (2006), Oliver et al. (2007), Brännström (2008), and Sykes and Kuyper (2009).
}

Received September 19, 2011; revised October 24, 2011, June 22, 2012, and June 26, 2012; accepted October 9, 2012; electronically published May 1, 2013

Comparative Education Review, vol. 57, no. 3.

(C) 2013 by the Comparative and International Education Society. All rights reserved. $0010-4086 / 2013 / 5703-0007 \$ 10.00$ 
Foster argued that geographic disparities are the most prominent educational inequalities in less developed countries: "The most serious form of educational inequality arises from regional disparities rather than from social, ethnic, or 'class' variables” (1977, 218). By the late 1990s, geographic inequality research was established as a legitimate scholarly tradition in the social sciences, though not without objections from mainstream economists. Scholarly evidence on group-level disadvantages conflicts with mainstream economists' "free-market prejudices" (Krugman 1995, 67), as research on geographic inequalities examines explanatory factors that are beyond an individual's control and undermines exclusively individualistic explanations of inequality.

Rural-urban disparities have been at the core of policy debates on education in developing countries. In Iran (Kamyab 2008), Turkey (Dundar and Lewis 1999), Russia (Roshchina 2004; Konstantinovskiy 2012), and Romania (Voicu and Vasile 2010), which are geographically close to Georgia, there are significant differences in access to higher education between applicants from rural areas and those from urban areas. Scholars argue that the roots of inequalities in access to higher education lie within academic achievement and attainment at earlier stages of education. In developing countries, there are obvious rural disadvantages, as more urbanized areas have better education systems (Lee 2002; Zhang 2006).

In this article, I examine the case of Georgian higher education admissions to illustrate the consequences of the state's equal treatment of applicants despite their unequal experiences and prior educational opportunities. Specifically, this article answers the following research questions: How is residential location associated with gaining admission to higher education for those who participate in the university selection examinations? How do households in selected districts and national policy makers explain higher education admission opportunities for the rural poor?

In 2005, Georgia declared a commitment to equality in higher education admissions by establishing a new policy of centralized selection examinations. The outcome of the nationwide competition is based on test scores obtained in the Unified National Examinations (UNEs). Since then, the government's discourse has revolved around the argument that admission to higher education should be decided according to applicants' individual merit (Deputy Minister of Education and Science, September 9, 2010; head of National Examinations Center, September 17, 2010) rather than their ability to bribe members of entrance exam boards. There is some empirical evidence that this policy succeeded in eliminating prior corrupt practices in university admissions and created conditions for formally equal competition for all (see, e.g. Temple 2006; EPPM 2008; World Bank 2012). Nationwide polls suggest that the UNEs enjoy wide popular support in Georgia, as the system is unlikely to involve any subjective judgments in admissions decision making (see, e.g., Transparency International 2006; BCG Research 2007; Teacher Professional 
Development Center 2008). The government takes pride in this supposedly very successful reform and maintains that the policy is purely meritocratic, ensuring lifelong opportunities of university admission through equal competition (National Examinations Center 2006a).

Education policy research has consistently recognized both private and social benefits of higher education and demonstrated that equitable access to quality higher education remains a policy challenge across the globe. ${ }^{3}$ Although educational research sometimes treats equity and equality as synonymous terms (Jacob 2007; Kapur and Crowley 2008; Morley et al. 2009), in this context, equality is understood as equal treatment of all applicants to higher education. In contrast, an equitable system ensures that applicants are treated according to their prior education opportunities, which are often related to family background and geographic location. By analyzing the Georgian case, I argue that a higher education admissions model may guarantee equality but at the same time be inequitable.

For the purposes of this study, higher education admission is defined as the outcome of gaining admission to a higher education institution for those who participate in selection exams. Admission is therefore not synonymous with access. I define higher education access as encompassing the process through which aspirations to higher education are formed, selection of desired programs and institutions, preparation and application, actual admission, financial support allocation, and program completion. The focus of this article lies in the outcomes of the undergraduate admissions process only, that is, whether applicants were admitted or not to a university. Higher education institutions are government-recognized institutions of higher learning, which provide International Standard Classification of Education (ISCED) level-6 programs. Using the UNESCO (2011) classification, an ISCED level-6 qualification program is an undergraduate program leading to a bachelor's degree. In this article, the terms "university" and "higher education institution" are used interchangeably. Using logistic regression, I model admissions to determine odds of acceptance for rural and urban secondary school graduates who take the UNEs. I then examine applicants' test score achievement and their university choice-making to establish relative (dis)advantages associated with rurality of the area where applicants went to school. Qualitative data are used to enhance and illustrate quantitative trends stemming from a large-scale national examinations data set. Interviews with rural families and policy makers complement the statistical evidence on ruralurban differences in applicants' test achievement and practices of university choice-making. Secondary school location, I argue, is linked with opportu-

\footnotetext{
${ }^{3}$ See, e.g., Jallade (1978), Selvaratnam (1988), Ntshoe (2003), Clancy and Goastellec (2007), Marcenaro-Gutierrez et al. (2007), Zimmermann (2008), Morley et al. (2009), Marginson (2011), and Meyer et al. (2013).
} 
nities of entering higher education, leaving rural school graduates marginalized and urban school graduates relatively privileged.

In Georgia, as well as other post-Soviet countries, there is a lack of reliable data and analysis on disparities in higher education admissions, specifically as related to individuals' place of residence. Generally, across the literature, geographic differences are unidentified and tend to be ignored by policy makers, scholars, as well as the general public. By setting up the same rules for all when it comes to higher education admissions, public policies altogether ignore spatial differences in educational opportunities.

\section{Background}

Georgia is a small state in South Caucasus with a population of 4.4 million people, 53 percent of which live in urban areas. Half of the urban population, that is, one-fourth of the country's residents, are concentrated in the capital city, Tbilisi (GeoStat 2009).

Georgia qualifies as a lower-middle-income country by the World Bank classification and a low-income economy by the United States Agency for International Development (USAID) classification. It has been in political, economic, and social transition from a centrally planned economy and communist government to a market economy and democratic government since gaining independence in 1991. After the dissolution of the Soviet Union and the collapse of the state collective farms, living conditions, as well as educational opportunities of the rural population, worsened dramatically in postSoviet countries. Collective farms used to provide an array of education, health, and housing-related social services, but in the 1990s, those services were lost, and rural disadvantage (in terms of family incomes, travel costs, and high-skill job opportunities) became very acute (UNICEF 2001; Cukrowski 2006).

Scholars and international organizations have noted that in the 1990s, the quality of schooling was much poorer in rural than in urban areas in post-Soviet countries. A UNICEF report using quantitative and qualitative data from post-Soviet countries in the first decade of transition found "considerable evidence that access to education and the quality of schooling are notably worse in rural areas" (UNICEF 2001, 77). One of the reasons for such disparities may be related to the variations in state expenditure on education. In 2001, Georgia was among the top 10 countries in the world spending the least on education as a percent of their gross domestic product (World Bank 2009).

Prior to the introduction of the centralized admissions system in 2005, secondary school graduates who intended to pursue academic higher education could choose from the following three options: attend a public higher education institution as a state-sponsored student, enroll at a public higher education institution as a fee-paying student, or enroll at a private, for-profit, 
higher education institution. For admission to a public university, eligible candidates had to take institution-specific entrance examinations. The main barrier to state-sponsored public higher education places was a deeply rooted tradition of informal payments in the form of direct bribes and/or private tutoring. Private tutoring was not only a way of supplementing public secondary school curriculum but also a form of bribery. Reportedly, tutoring with an entrance exam board member guaranteed admission to a public institution (Lorentzen 2000). ${ }^{4}$

To address the admissions barrier in the form of informal payments, and in the spirit of the commitment to formal equality, the Ministry of Education and Science introduced the UNEs in 2005 as a part of a new, allegedly meritocratic, admissions policy. Since 2005, the UNEs take place once a year to select students for public as well as private higher education. All applicants are required to take three compulsory tests: general aptitude (GAT), a foreign language of their choice (English, German, French, or Russian), and Georgian. An applicant may also sit for one or more elective exams, in case the departments that the applicant selected require an elective test. ${ }^{5}$

Document analysis of the National Examinations Center (NAEC) annual information booklets and reports demonstrate that, by design, the entirely automated admissions process in Georgia consists of three main components: test scores obtained in entrance exams, the chosen program of study (identified before taking the exams), and the number of available places in that chosen program for the upcoming academic year. ${ }^{6}$

Applicants must indicate their preferred program of study on their application forms, before taking the entrance exams. An applicant can gain admission to only one program of study at the specific higher education institution indicated in their application. After the applicant's competitive test scores are established, the university and the program of study are determined by a computer. ${ }^{7}$ Thus, applicants do not have to make enrollment decisions; that is, they do not receive admissions offers to choose from. Instead, they choose several higher education institutions before taking the

\footnotetext{
${ }^{4}$ In Georgia, the informal price for a spot at a public university could reach from $\$ 100$ to $\$ 20,000$ per applicant, depending on the prestige of the university and applicant qualifications (Lorentzen 2000; Janashia 2004).

${ }^{5}$ In 2009, elective exams were: literature, mathematics, history and social sciences, and natural sciences (with a focus on chemistry, physics, or biology).

${ }^{6}$ NAEC (2005, 2006a, 2006b, 2007a, 2007b, 2008a, 2008b, 2009a). Corruption practices in the Georgian higher education in the pre-2005 period, which I describe in greater detail elsewhere (Chankseliani 2013b), were similar to those in the rest of the eastern European and Eurasian countries overviewed by Stephen Heyneman, Kathryn Anderson, and Nazym Nuraliyeva (2008).

${ }^{7}$ An applicant's scores are first ranked against all other applicants who named the same program of study and university combination as their first choice. If the applicant's test scores are such that the applicant falls among the predefined number of top applicants that can be accepted to the program involved, the applicants' other choices are disregarded. Otherwise, his or her scores are ranked consecutively against those who applied for every subsequent choice that the applicant has made.
} 
UNEs and receive an admission offer for only one of them, depending on their entrance exam scores.

The number of open places at the universities is established through the national institutional accreditation undertaken by the government of Georgia. From 2005 to 2009, the accreditation process was continually revised, resulting in dramatic changes in the number of annually available university seats. The number of higher education institutions in the Georgian higher education system was reduced from 244 in 2004 to 43 in 2007 and then expanded to 58 in 2009 (National Center for Education Accreditation 2006; National Examinations Center 2009b). The former head of the National Center of Education Accreditation mentioned in an October 11, 2010, interview that the number of accredited higher education institutions increased because the political will for limiting the number of admissions offers declined, resulting in the reestablishment of a number of higher education institutions that had been closed prior to 2008. The analysis of the examinations data shows that considerable changes in the number of universities were reflected in dramatic year-to-year differences in admissions ratios. ${ }^{8}$ The lowest admissions ratio in 5 years was in 2007 (40.2 percent), and the highest admissions ratio was in 2009 (80.5 percent). The accreditation process that determined the number of annually available seats between 2005 and 2009 did not aim to assess the quality of teaching or research and was solely concerned with the evaluation of the physical infrastructure of the institutions (National Center for Education Accreditation 2006).

In view of the Georgian socioeconomic reality and university admissions system described above, I will now provide an overview of the methodology used in the study and highlight the findings stemming from the analysis of the national data sets and in-depth interviews. I will then discuss their policy implications.

\section{Methods}

This two-phase project combines evidence from the analysis of nationwide secondary data with the primary data obtained through in-depth interviews (fig. 1). As a compatibilist, I adopt a mixed-methods design in order to take advantage of the strengths of both the quantitative and qualitative paradigms. This mixed-methods design is rare among researchers studying spatial inequality, who usually conduct either large-scale aggregate data analysis or small-scale qualitative studies (Tickamyer et al. 2007).

\section{Quantitative Data}

The UNE pooled data over a 5-year period are the major quantitative data source used in the study. This consistent, homogeneous data set includes

\footnotetext{
${ }^{8}$ The admissions ratio is the total admissions to academic programs, expressed as a percentage of applicants in a given academic year.
} 


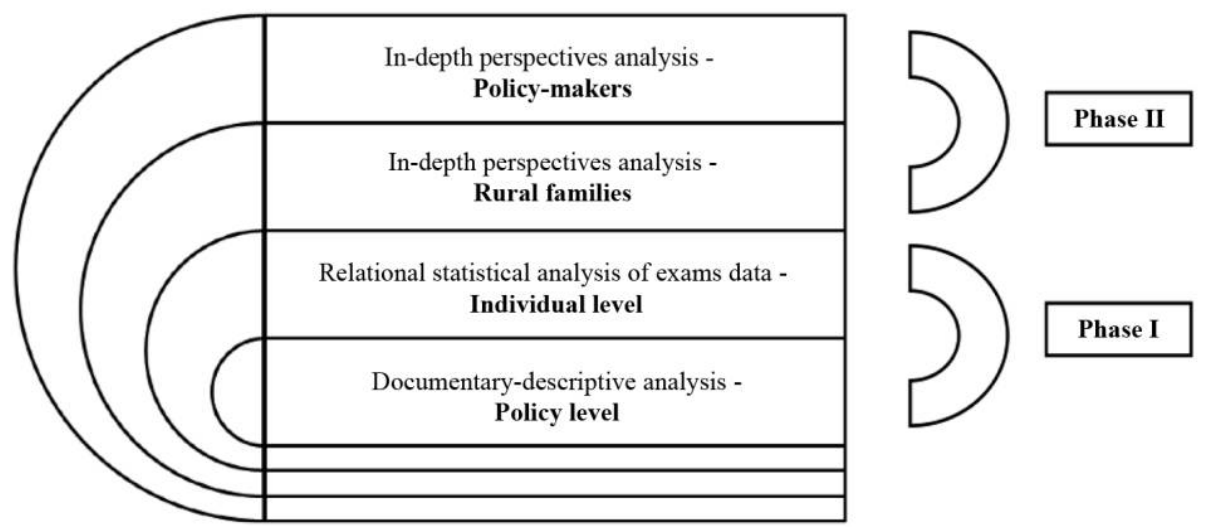

Fig. 1.-Research design

the entire target population of approximately 150,000 applicants. It has been put together by NAEC using the personal information provided by the applicants when registering for the UNEs (secondary school, gender, age, choice of university/programs of study) together with their UNE scores and outcomes of the selection competition. ${ }^{9}$ The variables used in the quantitative analysis relate to applicants' demographic characteristics, outcomes of UNEs for each applicant, and characteristics of schools and higher education institutions.

Demographic variables. - The gender variable classifies applicants into two categories: males and females. Exam year is an ordinal measure denoting the year in which an applicant took the UNEs; this variable has five categories, referring to the years from 2005 to 2009.

Birth date is a continuous variable, with the absolute majority (95 percent) of applicants in the period 2005-9 being born between 1987 and 1991. This trend implies that the population included in this study spent their early childhood and school years in a poor transition state with a failing education system.

School graduation time is a three-category measure indicating whether applicants graduated in the year in which they took the UNEs, any time before the examination year, or whether they are extern graduates. ${ }^{10} \mathrm{Al}-$ though people can take exams at any point in their lives, 95 percent of applicants in the period 2005-9 were recent school graduates.

\footnotetext{
${ }^{9}$ The data set contained few missing values, as this is the government data that were used to admit applicants to universities nationwide.

${ }^{10}$ An extern graduate is a person who passes extern exams in secondary school subjects in order to get a certificate of secondary education without receiving formal secondary schooling (Ministry of Education and Science of Georgia 2010).
} 
The language in which applicants passed the GAT is taken as a proxy for applicant minority status. A binary variable classifies applicants into Georgianlanguage speakers (took the GAT in Georgian) and non-Georgian-language speakers (took the GAT in Russian, Azeri, or Armenian).

Unified National Examinations variables. - A binary variable-admitteddenotes the success or failure in gaining admission. Test score variables are continuous on a scale of $0-100$, with higher scores indicating higher achievement. Each variable carries the name of the examination: GAT, Georgian, or foreign language.

School/higher education institution variables. - A separate measure was constructed to rank universities by prestige. Student cohort quality, as indicated by their average scores in compulsory examinations, is taken as a proxy of institutional quality. For this purpose, the scores in all three compulsory exams were summed up for each applicant, and an average sum of scores was calculated for each higher education institution. Mean scores were then ranked and prestige percentiles established: least prestigious (below 20th percentile), second-least prestigious (20th-40th percentile), medium prestige (40th-60th percentile), second-most prestigious (60th-80th percentile), and most prestigious (above 80th percentile).

The UNEs data set was complemented by the data from the Ministry of Education and Science to establish the type and location of secondary schools that applicants have graduated from. The school-type variable is binary and differentiates public (state-owned) from private (non-state-owned) school graduates.

The main question predictor is rurality of the area where an applicant graduated from a secondary school. Thus, secondary school location is used in this study as the indicator of applicant residential origin. Two variations of the same measure are used in the analysis: five-category and two-category rurality. The latter is binary and differentiates rural from urban areas. The five-category variable classifies applicants according to the location of their secondary school in mountainous villages, villages, towns, big cities, and the capital. The categorization process was broadly based on the government's classification of secondary schools by location for school financing purposes. ${ }^{11}$

Rurality is a composite, multidimensional construct that combines several educational, socioeconomic, and cultural features that applicants from different types of localities have. These distinct and interrelated components of

\footnotetext{
${ }^{11}$ In the period under discussion, there were three categories of per student secondary education vouchers in Georgia-for urban, rural, and mountainous rural schools (Government of Georgia 2007). My coding for rural and mountainous rural follows the government classification (Ministry of Education and Science of Georgia 2009). However, the task of subcategorizing the schools under the urban voucher financing category in the Ministry of Education and Science data set was more complicated. I subdivided this category into three for a higher level of precision. Although the capital was easily distinguishable, I had to differentiate between big cities and towns. The Statistics Department of Georgia Yearbooks data (GeoStat 2009) were used to distinguish the six biggest cities by population from the rest of the urban areas.
} 
the construct are explicated in the qualitative part of the project. The quantitative analysis treats the construct as one whole.

There has been an extensive debate between advocates and critics of multidimensional construct utilization. Opponents argue that such constructs are ambiguous and explain less variance in the outcome than would have been explained by including the different components of the construct separately in the model. ${ }^{12}$ However, proponents maintain that multidimensional constructs are excellent for the purpose of holistic representation of complex phenomena; also, such constructs help explain larger variance in the outcome. ${ }^{13}$ The choice of using the composite construct is explained by my interest in establishing the cumulative detrimental impact of residential origin. It would have been useful to model relationships using the components of this construct separately and to compare the two models. Unfortunately, this is impossible because of the unavailability of the data on each component of the construct.

\section{Qualitative Data}

In phase 2, audiorecorded, semistructured interviews were used to obtain empirically rich qualitative data from the families of adolescents born between 1986 and 1991 and selected policy makers (fig. 1). The interview data help to interpret and illustrate quantitative findings.

Families were selected in four largely rural districts of Georgia: Chiatura, Oni, Khoni, and Khulo. Among the criteria used in the district selection process was the fact that those districts had significantly higher or lower proportions of applicants gaining admissions than would have been expected considering their poverty levels (fig. 2). On average, districts with higher levels of poverty have lower admission ratios. Districts at or above the 90th percentile of the distribution, that is, the top 10 percent, have been assumed to be the poorest. Eight such districts were identified with 28.4 percent or more of their residents being poverty subsistence recipients. I avoided the four poorest districts in the country and focused on the next four within the top 10 percent.

The interviews were conducted only in rural areas of the selected districts, as the intention was to acquire an in-depth understanding of rural disadvantage. I collected 16 stories of success and failure by interviewing two families whose members gained university admission through the UNEs and two families whose members failed to gain admission in each district.

Respondents were selected using a random walk sampling technique. The random walk technique is when a researcher follows a random route.

\footnotetext{
${ }^{12}$ See, e.g., Hattie (1985), Gerbing and Anderson (1988), Schneider et al. (1996), Johns (1998), and Paunonen et al. (1999).

${ }^{13}$ See, e.g., Roznowski and Hanisch (1990), Hulin (1991), Ones and Viswesvaran (1996), and Hanisch et al. (1998).
} 


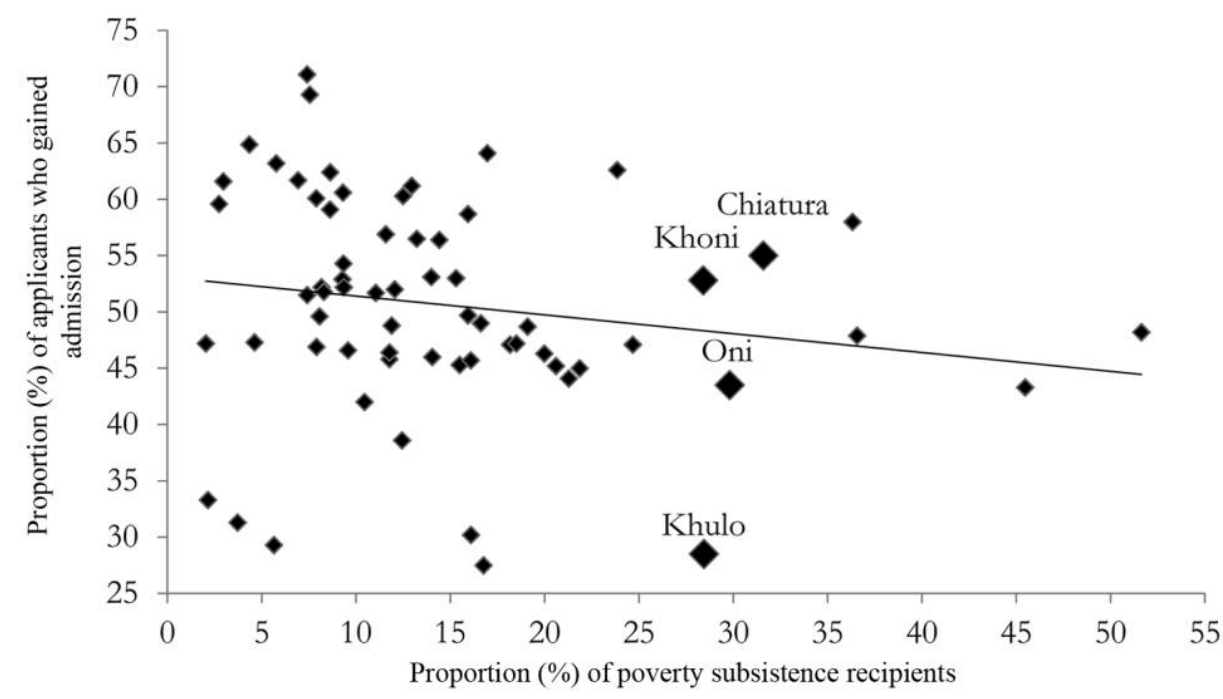

Fig. 2.- Simple regression analysis of poverty rates on admission ratios, by district. Source.GeoStat 2003; Social Service Agency 2009; National Examinations Center 2009a.

This technique has been used in empirical studies in developing countries or disadvantaged areas in developed economies, ${ }^{14}$ as it does not depend on the availability of registered voter databases and allows the researcher not to miss those households that may not be officially registered even when such data are available (Law et al. 2004). Upon arriving in the first village of the district, ${ }^{15}$ I chose the first person I encountered and explained the purpose of my visit, then asked that person to identify households where a family member had participated in the UNEs in the period 2005-9. Upon completing each interview, I would continue walking and engage in conversation with the next person I met. There was an enormous interest in my project, and people in all the four districts gladly agreed to communicate. There was not a single case of rejection from potential interviewees. Interviews were conducted during the summer and early fall of 2010. The vacation period was chosen with a view to interviewing applicants together with their parents. Indeed, most of them were spending the vacation at home.

The in-depth interviews were semistructured (see the appendix, available in the online version of this article, for the protocols). An interview schedule consisted of general topics for investigation. The interviews started with ques(2011)

${ }^{14}$ See, e.g., Henry et al. (2003), Law et al. (2004), Ranson et al. (2006), and Vinke and Lonergan

${ }^{15}$ The first village in each district was the closest village to the central highway and, possibly, one of the most priviliged in the district in terms of having the easiest access to roads and transportation. 
tions on contextual variables, ${ }^{16}$ followed by open-ended questions on preestablished topics. I began with a small set of open-ended questions and encouraged interviewees to provide further details about subjects of interest. Such an approach allowed me to fully explore emergent ideas and themes as the interview progressed. All interviews were conducted in Georgian, as all families were Georgian-speaking; I did not encounter any minority families in the areas where I conducted interviews.

Aiming at the generation of information that might contribute to the introduction of education policies that are more equitable for the disadvantaged, I engaged policy makers in the research process. A convenience sampling technique was used to select politically important figures. Relying on my prior experience of working for the Ministry of Education and Science, I selected top-level policy makers who were currently in office-the deputy minister of education and science, who is directly responsible for higher education, the head of the National Examinations Center, and the head of the National Curriculum and Assessment Center. I also interviewed top-level policy makers who were in office between 2005 and 2009: the head of the National Curriculum and Assessment Center and the head of the National Center of Education Accreditation.

The interviews with families and policy makers were analyzed using thematic content analysis, which involved the following five stages. First, the audiorecorded interviews were transcribed. Second, I engaged in close reading of the transcribed data, the so-called immersion, which was informed by relevant literature. A traditional paper-and-pencil method was used to break the narratives into themes and subthemes of interest. I took each narrative through a systematic process of analysis, noting in particular the passages related to rural life, school quality, and school choice. Third, I selected substantive statements in the narratives and matched them to the previously identified themes and subthemes. Fourth, I translated thematically arranged statements into English. Finally, the themes were merged into a narrative expanding on and interpreting spatial inequalities in Georgian higher education admissions.

The numeric evidence about the role of residential location in admissions was thus complemented with the constructivist accounts of possible reasons for spatial inequalities in admissions. The two bodies of evidence inform each other in important ways. While some results from quantitative analysis were used to give coherence and direction to the qualitative component of the study, the use of qualitative research helped illustrate and explain quantitative findings. Thus, the mixed-methods design allowed for the presentation of a more complete picture by highlighting major trends in higher education

\footnotetext{
${ }^{16}$ Age, ethnicity, income, education, gender, occupation, family size, and residence.
} 
admissions and providing some in-depth insights about possible causes of inequalities.

\section{Data Analysis and Results}

Whereas slightly more than half of the Georgian population lives in urban areas (53 percent), urban students are largely overrepresented within the higher education system. They made up, on average, 81 percent of admitted cohorts between 2005 and 2009. This may be due to three related factors: rural school graduates may be applying to higher education in lower proportions; when they choose to take entrance exams, their performance may be lower; and, for a given level of performance, they may have lower odds of gaining admission. This article does not look at spatial differences in tertiary aspirations as expressed in school graduates' decisions to apply to a higher education institution and to take the UNEs. The focus of the study is on the chances of gaining admission for those who aspire to higher education, as indicated by their participation in the entrance examinations.

Cross tabulation of admission by rurality of applicant origin shows that among those who participate in the nationwide selection exams, 63.1 percent of urban and 46.2 percent of rural applicants gain admission. Below, I explore the complex nature of spatial inequalities in Georgian higher education admissions by using the mixed evidence from large-scale national examinations and in-depth interview data.

\section{Modeling Admissions to Georgian Higher Education}

Binary logistic regression has been used to model the odds of gaining admission as a function of independent variables. Input variables were selected based on the research question, supporting substantive theory, and logic. The following equation specifies the logistic relationship:

$$
L_{i}=\ln \left(\frac{P}{1-P_{i}}\right)=Z_{i}=\beta_{0}+\sum \beta_{1} X_{1},
$$

where $L_{i}$ is the natural log of the odds of gaining admission, also called the logit; $Z i$ is a linear combination of independent variables $\left(b_{0}+b_{1} X_{1}+b_{2} X_{2}\right.$ $\left.+b_{3} X_{3}+\ldots+b_{n} X_{n}\right)$; and $P_{i}$ represents the probability of gaining admission, which ranges between 0 and 1 . The expression $1-P_{i}$ represents the probability of not gaining admission. Results are presented in table 1 .

Model A shows that, while holding other variables constant, the odds of urban school graduates gaining admission are 1.22 times as high as the odds of rural school graduates. Higher GAT scores are associated with higher odds of gaining admission. Every positive unit difference in the GAT is associated with 1.16 times higher odds of university admission. Older, private school graduates, and Georgian-speaking females seem to have higher odds of gaining admission than younger, public school graduates, and minority males. 
TABLE 1

Taxonomy of Binary Logistic Regression Models Predicting Higher Education Admission, 2005-9

\begin{tabular}{|c|c|c|c|c|c|c|}
\hline \multirow[b]{2}{*}{ Predictors } & \multicolumn{2}{|c|}{ Model A } & \multicolumn{2}{|c|}{ Model B } & \multicolumn{2}{|c|}{ Model C } \\
\hline & $B$ & $\operatorname{Exp}(B)$ & $B$ & $\operatorname{Exp}(B)$ & $B$ & $\operatorname{Exp}(B)$ \\
\hline Constant & $\begin{array}{l}-65.8 * * \\
(21.5)\end{array}$ & 0 & $\begin{array}{c}-330.6 * * * \\
(17.3)\end{array}$ & 0 & $\begin{array}{l}-60.7 * * \\
(23.1)\end{array}$ & 0 \\
\hline GAT & $\begin{array}{l}.15^{* * * *} \\
(.001)\end{array}$ & 1.16 & & & $\begin{array}{l}.10 * * * \\
(.001)\end{array}$ & 1.10 \\
\hline Georgian & & & & & $\begin{array}{l}.04 * * * \\
(.001)\end{array}$ & 1.04 \\
\hline Foreign & & & & & $\begin{array}{l}.03 * * * \\
(.001)\end{array}$ & 1.03 \\
\hline Rurality (urban areas) & $\begin{array}{l}.20 * * * \\
(.02)\end{array}$ & 1.22 & $\begin{array}{l}.80 * * * \\
(.01)\end{array}$ & 2.22 & $\begin{array}{l}-.19 * * * \\
(.02)\end{array}$ & .83 \\
\hline Birth date & $\begin{array}{l}.03^{* *} \\
(.01)\end{array}$ & 1.03 & $\begin{array}{l}.17 * * * \\
(.01)\end{array}$ & 1.18 & $\begin{array}{l}.03^{*} \\
(.01)\end{array}$ & 1.03 \\
\hline $\begin{array}{l}\text { Language minority status } \\
\text { (Georgian) }\end{array}$ & $\begin{array}{l}.50 * * * \\
(.06)\end{array}$ & 1.64 & $\begin{array}{l}.50 * * * \\
(.04)\end{array}$ & 1.64 & $\begin{array}{l}.54 * * * \\
(.07)\end{array}$ & 1.72 \\
\hline $\begin{array}{l}\text { School type (private } \\
\text { school) }\end{array}$ & $\begin{array}{l}.07^{*} \\
(.03)\end{array}$ & 1.07 & $\begin{array}{l}.27 * * * \\
(.02)\end{array}$ & 1.31 & $\begin{array}{l}-.01 \\
(.03)\end{array}$ & .99 \\
\hline Gender (female) & $\begin{array}{l}.15^{* * * *} \\
(.02)\end{array}$ & 1.16 & $\begin{array}{l}.02 \\
(.01)\end{array}$ & 1.02 & $\begin{array}{l}-.52 * * * \\
(.02)\end{array}$ & .59 \\
\hline \multicolumn{7}{|l|}{ Year: } \\
\hline 2005 vs. 2009 & $\begin{array}{l}-2.743 * * * \\
(.05)\end{array}$ & .06 & $\begin{array}{l}-.83 * * * \\
(.04)\end{array}$ & .44 & $\begin{aligned}- & 2.35^{* * * *} \\
& (.05)\end{aligned}$ & .10 \\
\hline 2006 vs. 2009 & $\begin{array}{c}-2.16^{* * * *} \\
(.04)\end{array}$ & .12 & $\begin{array}{l}-.74 * * * \\
(.03)\end{array}$ & .48 & $\begin{array}{c}-2.25 * * * \\
(.04)\end{array}$ & .11 \\
\hline 2007 vs. 2009 & $\begin{array}{l}-3.10^{* * * *} \\
(.03)\end{array}$ & .05 & $\begin{array}{l}-1.75 * * * \\
(.02)\end{array}$ & .17 & $\begin{array}{c}-3.57 * * * \\
(.03)\end{array}$ & .03 \\
\hline 2008 vs. 2009 & $\begin{array}{l}-.13^{* *} \\
(.05)\end{array}$ & .88 & $\begin{array}{l}.06 \\
(.04)\end{array}$ & 1.07 & $\begin{array}{l}-.46^{* * *} \\
(.05)\end{array}$ & .63 \\
\hline$N$ & \multicolumn{2}{|c|}{149,239} & \multicolumn{2}{|c|}{149,239} & \multicolumn{2}{|c|}{149,239} \\
\hline$-2 \log$ likelihood & \multicolumn{2}{|c|}{$83,441.5$} & \multicolumn{2}{|c|}{$140,606.7$} & \multicolumn{2}{|c|}{$75,853.6$} \\
\hline$R^{2}$ Nagelkerke & \multicolumn{2}{|c|}{62.3} & \multicolumn{2}{|c|}{17.6} & \multicolumn{2}{|c|}{66.7} \\
\hline
\end{tabular}

Source.-Own calculations based on GeoStat (2009), Ministry of Education and Science of Georgia (2009), and National Examinations Center (2009a) data.

NoTE.-Cell entries are estimated regression coefficients and standard errors. GAT = general aptitude test. $* P<.05$.

$* * P<.01$.

$* * * P<.001$.

Differences in the odds of admission by exam year are large. The regression coefficients for the exam years confirm that one of the significant predictors of gaining admission during the study period has been the exam year, a factor largely dependent on chance and less likely to be related to student characteristics. Considering the regression coefficients of exam years as well as the drastic decrease in the number of higher education institutions from 244 in 2004 to 43 in 2007 and later expansion to 58 in 2009, it appears that differences in admissions by exam year are linked with the continual process of institutional accreditation described above. The large fluctuations in the number of universities and annually available seats would affect the chances of marginal applicants, who would most likely be public school graduate rural males, as evidenced by the modeling exercise (table 1). 
The correct classification rate and Nagelkerke pseudo- $R^{2}$ have been used to assess the goodness-of-fit of model A. The prediction is 86.7 percent accurate for those applicants who gained admission and 78.9 percent accurate for those who did not gain admission. Overall, this model correctly classifies 83.6 percent of applicants. The independent variables included in the model, therefore, are useful predictors that distinguish applicants who gained admission from those who did not, since the classification accuracy rate is substantially higher than the accuracy attainable in the null model (overall percentage $=59.9$ percent). The pseudo- $R^{2}$ establishes fairly strong association (Nagelkerke $R^{2}=62.3$ ). No multicollinearity issues have been detected among independent variables, and none of the independent variables in this analysis had a standard error larger than 2.0.

This model, however, does not fully control for all the procedural factors. As previously indicated, the UNEs are designed such that applicant test scores, choice of program/university, and the number of available places are all accounted for in an automated manner. Out of the three factors, model A partially controls for test performance by including GAT scores, exam year is used as a proxy for annually changing number of places, and program choice is not accounted for. It can, therefore, be assumed that in model A, the composite construct of rurality brings together some variation in test scores and all variation in program/university choice by geographic origin, when controlling for GAT score, demographic factors, and exam year.

In order to further explicate the findings from model $\mathrm{A}$, it is important to look at alternative models first without any test scores and then with all compulsory test scores included. As expected, when ignoring test scores (table 1, model B), rurality has a larger effect on the odds of gaining admissionthe odds of gaining admission for urban applicants are 2.2 times higher than for rural applicants - than in model A, where we control for the applicant GAT score and the odds of gaining admission for urban applicants are 1.2 times higher than the odds for rural applicants. This is because rural and urban applicants significantly differ in their scores on the GAT, ${ }^{17}$ and the inclusion of this variable in the model removes some explanatory power from the composite effect of rurality.

When including all compulsory test scores (table 1, model $\mathrm{C}$ ), rurality reflects the variation in program/university choice, since the other two components of admission (test scores and exam year) are largely accounted for. However, when all the compulsory scores, exam year, and demographic characteristics are included in model $\mathrm{C}$, the sign of the question predictor changes. In other words, if rural and urban applicants of similarly controlled demographic characteristics accumulate the same scores in the compulsory subjects in the same exam year, rural applicants have higher chances of

\footnotetext{
${ }^{17}$ Average scores on the GAT for applicants from different geographic areas increase consistently as we move from mountainous villages $(M=39.8)$ to the capital $(M=50.7)$
} 
gaining university admission. This surprising finding generates two further questions: What is the likelihood that rural and urban school graduates score the same on compulsory subject tests? What may be explaining higher odds of admission for an average rural applicant who accumulates the same compulsory test scores as an average urban applicant?

Multiple regression analysis was used to predict test scores in each of the three compulsory subjects-GAT, a foreign language, and Georgian-separately. The analysis demonstrated that while holding gender, language minority status, birth date, school type (public/private), school graduation time, and exam year constant, applicants who graduated from a secondary school in a more rural location tend to score considerably lower in all three compulsory exams. Associations between applicant residential origin and their compulsory scores are consistently significant $(P<.001)$ across all three models. The largest differences by rurality are observed in the foreign-language test. For instance, applicants who graduate from a secondary school in a rural mountainous village score on average 16.3 points (0.7 SD) lower than applicants from the capital on the foreign-language test. The difference between the average scores of an applicant from a village and one from the capital is 13.6 points $(0.6 \mathrm{SD})$; it is 9.2 points $(0.4 \mathrm{SD})$ between those of an applicant from a town and one from the capital, and 4.7 points $(0.2 \mathrm{SD})$ between those of an applicant from a big city and one from the capital.

In those less likely circumstances when rural and urban applicants of similarly controlled demographic characteristics accumulate the same scores, the odds of rural applicants gaining admission are higher than the odds of urban applicant. Qualitative as well as quantitative evidence from the study show that this outcome may be due to the fact that rural school graduates apply to less prestigious universities. Multinomial logistic regression was conducted to estimate the degree to which naming universities of different prestige as the first choice is predicted by applicant area of origin, when controlling for applicant general aptitude. The population groups admitted to the least prestigious universities (below 20th percentile), the second-least prestigious (20th-40th percentiles), the medium prestige (40th-60th percentiles), and the second-most prestigious (60th-80th percentiles) were compared to those who gained admission to the most prestigious universities (above 80th percentile). Thus, the reference category for the dependent variable is the group of most prestigious universities, and the reference category for the main predictor is the group of applicants from the capital. Table 2 presents the odds ratios for the contrasts by prestige categories.

Applicants with higher general aptitude tend to have consistently higher odds of applying to a university in the most prestigious category. When holding applicants' measured aptitude constant, there are large differences in the odds of applying to the most prestigious universities for applicants from different urbanicity areas (table 2 ). Of two applicants with the same general 
TABLE 2

Multinomial Regression Modeling of the First Choice University Prestige

\begin{tabular}{|c|c|c|c|c|c|c|c|c|}
\hline \multirow[b]{2}{*}{ Predictors } & \multicolumn{2}{|c|}{$\begin{array}{l}\text { Least Prestigious } \\
\text { (below 20th } \\
\text { Percentile) } \\
\text { Compared to } \\
\text { Most Prestigious } \\
\text { (above 80th } \\
\text { Percentile) }\end{array}$} & \multicolumn{2}{|c|}{$\begin{array}{c}\text { Second-Least } \\
\text { Prestigious } \\
\text { (20th-40th } \\
\text { Percentile) } \\
\text { Compared to } \\
\text { Most Prestigious } \\
\text { (above 80th } \\
\text { Percentile) }\end{array}$} & \multicolumn{2}{|c|}{$\begin{array}{l}\text { Medium Prestige } \\
\text { (40th-60th } \\
\text { Percentile) } \\
\text { Compared to } \\
\text { Most Prestigious } \\
\text { (above 80th } \\
\text { Percentile) }\end{array}$} & \multicolumn{2}{|c|}{$\begin{array}{l}\text { Second-Most } \\
\text { Prestigious } \\
\text { (60th-80th } \\
\text { Percentile) } \\
\text { Compared to } \\
\text { Most Prestigious } \\
\text { (above 80th } \\
\text { Percentile) }\end{array}$} \\
\hline & $B$ & $\operatorname{Exp}(B)$ & $B$ & $\operatorname{Exp}(B)$ & $B$ & $\operatorname{Exp}(B)$ & $B$ & $\operatorname{Exp}(B)$ \\
\hline Intercept & $-.30 * * *$ & & $.36 * * *$ & & $1.28 * * *$ & & $1.04 * * *$ & \\
\hline Mountainous villages & $2.51 * * *$ & 12.34 & $1.87 * * *$ & 6.48 & $-.52 * * *$ & .59 & $-.19 * * *$ & .82 \\
\hline Villages & $1.87 * * *$ & 6.47 & $1.35^{* * * *}$ & 3.86 & $-.35^{* * *}$ & .70 & $-.09 * * *$ & .91 \\
\hline Towns & $1.64 * * *$ & 5.13 & $.92 * * *$ & 2.5 & $-.27 * * *$ & .76 & -.02 & .98 \\
\hline Big cities & $2.34 * * *$ & 10.34 & $1.96 * * *$ & 7.11 & $-.33 * * *$ & .72 & .03 & 1.03 \\
\hline GAT & $-.06 * * *$ & .94 & $-.05 * * *$ & .95 & $-.04 * * *$ & .96 & $-.03 * * *$ & .97 \\
\hline
\end{tabular}

SOURCE.-Own calculations based on National Examinations Center (2009a) data.

NoTE.-The reference category for the dependent variable is the group of most prestigious higher education institutions, and the reference category for the main predictor is the group of applicants from the capital. GAT = general aptitude test.

$* * * P<.001$.

aptitude, the odds for an applicant from a mountainous village to apply to a least prestigious institution rather than a most prestigious one are approximately 12 times as high as the odds for an applicant from the capital. Holding general aptitude constant, the odds of an applicant from a town or a village applying to the least prestigious institution rather than the most prestigious one are 5-6 times as high as the odds of an applicant from the capital doing so (table 2).

Overall, the full model fits the data well. The change in the likelihood ratio test is significant $\left(\chi^{2}=2.82, p=.000\right)$, which indicates that model $\mathrm{A}$ is significantly better than the intercept-only model. As indicated by the Nagelkerke pseudo- $R^{2}$, the association is of medium strength $\left(R^{2}=.226\right)$.

The finding that applicants from outside the capital tend to name the least and the second-least prestigious institutions as their first choice most frequently is not surprising if we consider it in the context of living costs and tuition prices. Using the same quantitative data, it has been shown that less prestigious institutions charge significantly lower tuition and are located outside the capital (Chankseliani 2013a). Interview data show that applicants and their families are not making higher education choices on equal grounds; they are instead constrained by an array of factors beyond their control. In circumstances where no grant is available to cover living costs for any student in the country, rural applicants, who are more likely to be poor, ${ }^{18}$ must overcome serious financial difficulties before naming one of the most prestigious higher education institutions as their first choice. Most of the interviewed

\footnotetext{
${ }^{18}$ An average monetary income in rural areas (67 GEL) amounts to approximately half of an average income in urban areas (128 GEL; Ivaschenko and Posarac 2008).
} 
families seem to have considered living costs together with tuition as major factors when making higher education choices. The choices of program and institution combinations are made at the time of application, before applicants sit for the UNEs. As it emerged from interviews, early decision making puts marginal applicants at a disadvantage. Rural families talked about the difficulty of making the right prediction of achievement at the UNEs, calling the decision of naming low-caliber institutions more "realistic."

As explained earlier, the entirely automated admissions procedure in Georgia is based on three main components: test scores obtained in the UNEs, choice of program, and the number of available places. Models A and $\mathrm{C}$ complement each other in portraying the empirical reality of higher education admissions in Georgia. In model A, where the composite construct of rurality brings together a portion of the unexplained spatial variation in test scores and full spatial variation in choice making, urban origin is associated with 1.22 times higher odds of gaining admission than rural origin. This difference in odds is further explicated in model C, where the compulsory test scores are accounted for. Here the composite construct of rurality reflects the variation in choice making. Model $\mathrm{C}$ shows that choice-making practices put rural applicants in an advantageous position over their urban peers when they are able to obtain the same scores as urban school graduates. This is unlikely, as demonstrated by the multiple regression models predicting test scores in each compulsory subject. Multinomial logistic modeling of applicant choices of universities as well as interview data shed further light on this finding, as they show that rural applicants tend to consistently apply to lower quality higher education institutions.

Thus, urban privilege as expressed in higher odds of gaining university admission tends to be associated with urban applicants' ability to score, on average, higher than rural applicants (model A). However, when holding test achievement on all compulsory subjects constant, rural applicants have higher odds of gaining university admission than their urban peers. This seemingly advantageous outcome is masking serious inequalities, as it is based on rural applicants' decisions to apply to less prestigious institutions. Many authors have shown that attendance to lower quality institutions may negatively affect lifetime opportunities by being associated with lower probability of graduation, less access to postgraduate studies, as well as lower wage premiums. ${ }^{19}$

\section{Rural Disadvantage Explained by Families and Policy Makers}

Interviews with rural families showed that secondary schooling experiences together with family economic status and sociocultural environment facilitate the marginalization of rural applicants in terms of university admissions. I analyze each of these themes below.

\footnotetext{
${ }^{19}$ See, e.g., Monks (2000), Carnevale and Rose (2003), Chevalier and Conlon (2003), Brand and Halaby (2006), Morley and Aynsley (2007), and Rivera (2011).
} 
Most of the interviewed families considered their villages extremely poor. From conversations I held with 16 families in four districts and from visual observations, I concluded that half of the families had some problems with subsistence provision. About half of them seemed too poor to afford minimum bills. The interviewed families were extremely concerned that they (and their neighbors) were unable to support some of the basic educational needs of their children. ${ }^{20}$ "Parents cannot afford to buy textbooks for their children under the circumstances when they can hardly make ends meet and purchase enough flour to bake bread," said the successful applicant's mother, who works as a teacher (family 4 in Oni, September 3, 2010).

Throughout the interviews with rural families and policy makers, chances of gaining admission were consistently associated with pupils' academic achievement. The general assumption was that a pupil who has high academic achievement at school usually gains admission to higher education. This finding is congruent with a traditional assumption of educational policy literature on test scores as an outcome indicator of previous schooling quality.

Almost all interviewees associated urban residence with better academic experiences. When compared to villages, urban areas were considered to offer better schooling and private tutoring opportunities. Most families had information about urban schools from relatives and friends living in urban areas; few compared their schools to those in Tbilisi, as they did not seem to have much information about them. Teaching quality together with schools' physical infrastructure were the two main factors of discontent among the families I talked to. School quality was a major issue of dissatisfaction not only for families of unsuccessful applicants but also for those who gained admission. A tendency to blame the school could often be detected in the narratives of the parents whose children failed or did not achieve competitive scores at the UNEs. For most of the families, the quality of foreign-language teaching was the most serious challenge. One of the successful applicants' families had a very strong opinion about the quality of Russian teaching at their local school: "This has always been the major academic problem in our village," the mother acknowledged (family 4 in Oni, September 3, 2010). The Russian teacher, as reported by the family, did not have any formal teaching qualifications; he learned the language while serving in the Soviet army decades ago. The student and her mother believed that the primary reason the applicant did not gain admission in the first year of application was that she had an underqualified teacher of a foreign language at school. "Foreign language is the only subject that you can do nothing about without a proper teacher," the student said (family 4 in Oni, September 3, 2010).

\footnotetext{
${ }^{20}$ Family 1 in Chiatura, August 31, 2010; family 2 in Chiatura, August 31, 2010; family 4 in Chiatura, August 31, 2010; family 2 in Khoni, September 2, 2010; family 4 in Khoni, September 2, 2010; family 4 in Khulo, September 1, 2010; family 1 in Oni, September 3, 2010; family 2 in Oni, September 3, 2010; family 4 in Oni, September 3, 2010.
} 
The NAEC head admitted that foreign-language teaching could be problematic in rural schools; however, NAEC had not "observed any dramatic differences between foreign language scores of rural and urban applicants" (September 17, 2010). The deputy minister also denied the possibility of spatial differences in academic achievement: "Nobody can assure me that they teach foreign languages better in Gldani or Isani-Samgori [districts in the capital] than they do in Ozurgeti or Samtredia [rural districts]" (September 9, 2010). The empirical analysis of the UNE data set does demonstrate, however, that applicants from all regions of Georgia score, on average, lower than applicants from Tbilisi in foreign languages. Comparison of average scores for the districts mentioned by the deputy minister shows that applicants from Ozurgeti $(M=46.5)$ and Samtredia $(M=46.3)$ districts have approximately half a standard deviation lower average scores in foreign languages than applicants from Gldani $(M=57.4)$ and Isani-Samgori $(M=$ 59.0).

Some of the former and current government officials admitted that there might be differences in school quality between rural and urban schools, particularly in foreign languages (former head of National Curriculum and Assessment Center, September 14, 2010; head of National Curriculum and Assessment Center, September 10, 2010). Foreign-language teaching quality in village schools has always been an issue, even in the Soviet past, according to the head of National Curriculum and Assessment Center (September 10, 2010). A possible reason for the lower quality teaching in rural areas, maintains the former head of National Curriculum and Assessment Center (September 14, 2010), could be a lack of qualified teachers.

The government, however, does not seem to be implementing any policy to eliminate rural educational disadvantage (former head of National Curriculum and Assessment Center, September 14, 2010; head of National Curriculum and Assessment Center, September 10, 2010). "Nothing is done specifically for rural areas, that would mean segregation, wouldn't it? We are working to improve school quality everywhere in the country" (head of National Curriculum and Assessment Center, September 10, 2010).

The interviewed families frequently mentioned concerns regarding educational infrastructure: lack of adequate school libraries, nonexistent or poorly equipped school labs, lack of accessible computers and Internet, shortage of maps, and lack of heating. School libraries, in particular, were a concern for many families because the conditions of poverty preclude them from being able to afford textbooks and extracurricular reading materials. Most of the parents who talked about the problem compared the current lack of adequate library in their children's schools to the Soviet past when libraries were more widely accessible and well stocked (family 1 in Chiatura, August 31, 2010; family 2 in Chiatura, August 31, 2010; family 3 in Khoni, September 2, 2010; family 1 in Oni, September 3, 2010). Whereas for parents Soviet 
schools serve as a reference point, for the young generation, schools in urban areas perform the same function.

Most of the families expressed discontent about school infrastructure: lack of heating (family 2 in Chiatura, August 31, 2010; family 4 in Chiatura, August 31, 2010), no maps to teach and learn geography (family 2 in Oni, September 3, 2010), wrongly sized desks and chairs and no sports facilities (family 2 in Chiatura, August 31, 2010), lack of natural science laboratories (family 2 in Chiatura, August 31, 2010; family 2 in Khoni, September 2, 2010; family 3 in Khoni, September 2, 2010; family 1 in Oni, September 3, 2010; family 4 in Oni, September 3, 2010).

Rural location induced a double disadvantage for the respondents as far as pursuing extracurricular activities is concerned. First, no art classes, theater performances, or other cultural activities were offered in any of the villages I visited. Second, the remote location increased the cost of pursuing those activities, as families had to incur transportation costs to an urban center. A mother of a successful applicant said that a family day trip to the regional center, including a theater and museum visit, would cost them around 100 GEL (US $\$ 61 ; 50$ percent of her monthly teacher salary at the time of the interview). Very often, she admitted, she would choose to buy clothes for her schoolchildren rather than take them to a theater or a museum (family 2 in Khulo, September 1, 2010).

Only two respondents, both teachers themselves and mothers of successful applicants, referred to the rural-urban differences in students' general abilities. One of them, a mother of a successful applicant and a teacher at a local school, shared the school's success story. She was proud that students from the school where she worked won second place in the regional intellectual competition. When asked who got first place, she named the school from the big city Batumi, which is the regional center: "Our kids could not outperform Batumi kids who are more swift and agile in their reasoning. Our children may know the answer but are not such quick thinkers as urban kids are" (family 2 in Khulo, September 1, 2010). In another district, a respondent mother provided a somewhat similar insight. She had some connections with young people from Tbilisi and did not see any difference in patterns of thinking between urban and rural kids. However, the kids from Tbilisi seemed to her to be more advanced, largely due to their familiarity with up-to-date informational technologies (family 3 in Oni, September 3, 2010).

The general conclusion from in-depth interviews was that respondents were not satisfied with the quality of schooling in their villages. As an aunt of an unsuccessful applicant said, all parents in their village think that any urban school is better than the village school: "Teachers in our village school may have good knowledge of their subjects but are often unable to share their knowledge with pupils. The only families who leave their children in 
our village school are those whose children are mentally deficient or extremely poor; they either do not understand that an urban school is so very much better or they cannot afford paying for the child's transport costs to travel to the town which is 15 minutes away by bus" (family 2 in Chiatura, August 31, 2010).

\section{Limitations}

The main findings of this study rely on the evidence stemming from the quantitative modeling, which provides a simplified depiction of a complex reality that can help to understand social phenomena. Any modeling exercise has obvious limitations. Simplifications of model building in the social sciences usually involve missing and ignoring several factors. Even relatively useful models carry with them a serious cost, as "once you have a model it is almost impossible to avoid seeing the world in terms of that model" (Krugman 1995, 71-72).

However, due to the nature of qualitative research, the data obtained in the second phase of the study are not statistically generalizable. Because I used semipurposive, nonprobability sampling in the qualitative phase of the study, I cannot state with confidence that the sample of rural families is representative either of the broad Georgian rural population or even of the districts where the interviewees reside. Instead, qualitative data, which may be subject to various interpretations by different readers, provide rich, contextualized understanding. Also, considering the interpretative nature of qualitative research, I might have introduced bias into the analysis of the interview data.

I tried to compensate for the weaknesses of qualitative and quantitative approaches by relying on their relative strengths. There are some concerns regarding omitted variable bias in the quantitative data analysis and generalizability in qualitative data analysis. Whereas in the first phase, I model existing relationships in the population, the interviews from the second phase provide in-depth, individual perspectives of rural families and policy makers, illuminating selected parts of quantitative findings. Thus, weakness minimization is promoted by combining descriptive precision (stemming from the qualitative analyses) with empirical precision (stemming from the quantitative analyses). This combination of nonoverlapping weaknesses and complementary strengths (Brewer and Hunter 1989) makes mixed methods useful.

\section{Discussion and Policy Implications}

This study has illustrated that equality of opportunity in the selection process does not necessarily guarantee equitable admissions to universities. An equitable system, as mentioned previously, would ensure that applicants are treated according to their prior educational opportunities, which are 
often related to family background. Quantitative analysis of the UNE data revealed some critical evidence on spatial inequalities in Georgian higher education admissions, and I have used qualitative analysis to show that access may strongly depend on prior educational opportunities in the Georgian setting. The present inquiry has uncovered a tension between individual merit and student diversity by geographic origin that arises when standardized test scores are the sole indicators of applicant merit and there is no consideration of prior schooling opportunities.

Below, I discuss the combined effect of lower chances of gaining admission, lower aspirations, and lower odds of completing secondary education on the underrepresentation of rural students in the Georgian higher education system. This is followed by the analysis of policy implications stemming from the empirical findings of this study, namely those related to a more contextualized approach in admissions, a new scheme of student financing, changes in timing of public funding allocation decisions, targeted compensatory policies at school level, and distance education options.

The outcome of area-based differences in educational opportunities is that the absolute majority-81 percent-of admitted cohorts come from urban centers. This is a morally unacceptable and economically unsustainable statistic in a country where 47.3 percent of the population resides in villages. Considering the literature on economic and social returns to bachelor's degree ${ }^{21}$ it may be hypothesized that spatial disadvantages in university admissions affect private returns of rural secondary school graduates as well as public benefits for Georgian society at large.

Underrepresentation of rural youth in Georgian higher education is a combined outcome of rural school graduates' lower chances of gaining university admission, their lower aspirations, and their lower odds of completing secondary education. Whereas this article examines spatial differences in admissions, the literature shows that rural pupils are disadvantaged also in terms of secondary school completion and higher education aspirations. As demonstrated by Shapiro et al. (2007), the rural-urban gap in secondary school enrollments is considerable, with rural areas having 10 percent lower enrollments than Tbilisi, where 96 percent of pupils are enrolled at the secondary level. As shown by Chankseliani (2012), those who complete secondary education exhibit different aspirations to university education depending on residential origin. In urban areas, every other school graduate applies to university, whereas in rural areas, only one in four makes a decision to take the UNEs. Therefore, the rural disadvantage in access is in fact much larger than that indicated by the admissions modeling exercise discussed here.

As revealed from the qualitative data analysis, rural disadvantage in the ${ }^{21}$

\footnotetext{
${ }^{21}$ See. e.g., Haveman and Wolfe (1984), Perna (2003), IHEP (2005), and Stransky and Good
} 
admissions process is linked with economic and cultural aspects of rural life. No single policy will eradicate this disadvantage and ensure lasting effects. Therefore, the policy options presented below should be viewed as components of an aggregate approach toward improving higher education admissions opportunities for those who reside in disadvantaged geographic areas.

In order to address the equity concerns outlined in this article, I suggest that student selection policies adopt a more contextualized approach. The Georgian higher education admissions system should be adjusted so that it accounts for differences in educational opportunities by location while still recognizing individual academic achievement. Contextualized admissions will address equity concerns by controlling for variations in educational opportunities by area when selecting academically successful pupils for higher education. For this purpose, a district-based ranking system can be established. District-based ranking is a summary of a student's test score achievement as compared with other students in the district's graduating class. Test scores of individual applicants in such a system would be ranked by districts, and that ranking would be considered for selection purposes. Admissions procedures based on applicant rank within the district would create a more diverse cohort than procedures based on applicant rank nationwide. The district-level determination of the "best" takes into account area-specific educational opportunities, whereas a national competition does not. For instance, nationwide, there will be applicants who score in the top 5 percent of their districts, top 10 percent, top 20 percent, and so on. An applicant from Vake District, one of the five districts of the capital, who achieved a score of 90 on a foreign-language test, and an applicant from the mountainous Khulo District who scored 34 on that same test might both be among the top 15 percent of their district graduating class, and therefore both would be considered within the top 15 percent of achievers nationwide. ${ }^{22}$ Thus, ranking of applicant test scores against all other applicants from the same district will show where each applicant falls within the district-level academic spectrum and will allow for adjusting test scores to geographic inequalities in educational opportunities.

The proposed district-based ranking resembles percent plans for admission to public universities in Texas, Florida, and California. ${ }^{23}$ In the US context, the benefits of such policies include increased diversity of admitted students (Lloyd et al. 2008) and more opportunities to enter public universities for students from high schools in rural areas, small towns, and midsize cities (Long et al. 2010; Tienda and Sullivan 2010). While the intention of

\footnotetext{
${ }^{22}$ Using the Unified National Examinations data for 5 years, I have calculated that these are the scores of students on the 85th percentile of the distribution in these two districts.

${ }^{23}$ These percent plans ensure that high school pupils who graduate above the preidentified ranking threshold of their class gain admission to public institutions in their state. Preidentified ranking thresholds differ by state-20 percent in Florida, 10 percent in Texas, and 4 percent in California (Tienda and Sullivan 2010).
} 
these policies is to increase access to those from underserved populations and from lower socioeconomic strata, the problem is that the plan's success depends on highly segregated schools: if a school is well integrated, the percent rule may no longer guarantee the diversity of admitted cohorts (Tienda and Sullivan 2010). Also, the policy may be associated with a decrease in retention and graduation rates of lower ranked minority students (Cortes 2010), and it may introduce an incentive to enroll in a high school with lower achieving peers (Cullen et al. 2011).

There is reason to believe that this particular set of benefits and drawbacks may not apply directly to Georgia, should similar plans be implemented there. In the US context, high school students are ranked at the school level. In contrast, the plan I propose suggests a district-level ranking. This would avoid unfairly privileging small schools. Also, whereas in the three US states the ranking takes into account only high school grades, in the Georgian case the ranking would focus on standardized test scores. Although the literature shows that school grades are far better predictors of success at universities than standardized test scores (Tienda and Sullivan 2010), the use of school grades for the purposes of admissions may carry a serious threat of corruption in a poor country like Georgia with a history of widespread corruption in the education sector.

Besides, as revealed through the quantitative evidence, rural applicants are extremely unlikely to apply to prestigious, high-quality universities, all of which are located in the capital. This finding is confirmed by the qualitative analysis showing that financial considerations related to living and tuition costs are prohibitive for rural families when selecting a higher education institution. A new scheme specifically designed to assist rural secondary school graduates in meeting costs could provide housing- and living-expense coverage to those rural students who gain admission to prestigious universities. Such a policy could influence rural applicants' choices, incentivizing them to apply to prestigious institutions by alleviating the burden of reallocation and living costs.

Another important factor that may also influence college-going choices is the timing of public funding allocation decisions. Experimental evidence from China, for example, shows that when a poor, rural applicant has learned about the available financial aid before finishing secondary school (instead of after gaining higher education admission), s/he may well make less distorted choices as far as pursing university education is concerned (Liu et al. 2011). The policy options above, however, do not address the main problem, which is that rural school graduates score significantly lower than urban school graduates across all compulsory examinations, most probably as a result of inequalities in their previous education. Internationally, applicants who have attended better secondary schools and/or have had (better) private 
tutors are better prepared for tests than those who have attended lower quality schools (Helms 2008).

Therefore, in order to address spatial differences in education outcomes in Georgia, school-level interventions will be required. Several policy options are available. First, the government could design and implement targeted compensatory policies at the preschool, primary, and secondary levels, which will give differentiated attention to poor rural communities, with a view to eradicating rural academic disadvantage. The UNE data can provide a solid basis for informed policy making regarding the determination of areas and schools in need of further support.

Second, distance education can also improve education quality in rural areas, ${ }^{24}$ by tackling the problems of geographic isolation and limited school resources, as well as difficulties in attracting and retaining qualified teachers. Distance education may include the provision of web-based, radio, and TV programs to reach geographically isolated schools and communities. Distance education possibilities should be explored especially as far as foreign-language instruction is concerned. Special attention should be paid to the improvement of foreign-language teaching in rural schools, as the largest inequalities in academic achievement are observed in foreign-language test scores. Highquality foreign-language teachers are likely to require considerable incentives for recruitment and retention at rural schools. Yet even if the government could afford to provide such incentives to foreign-language teachers only, such incentives might cause high levels of discontent among teachers of other subjects.

\section{Conclusion}

This study has made a contribution to both academic and policy-related debates on inequalities in tertiary education admission. Through the systematic and critical analysis of empirical data via a bifocal lens, it expands the range of international scholarly findings pertaining to spatial inequalities in higher education admissions and confirms that geography is an importantand understudied-stratifier in terms of educational outcomes. The article shows that within a highly competitive higher education system, applicants from selected locations are likely to be better able to meet university admissions requirements and enter the most demanding universities. Taken together, these findings are generally consistent with the existing (but small) literature that looks at spatial inequalities in access to higher education in this part of the world. ${ }^{25}$ While several post-Soviet countries have implemented centralized examinations for higher education admissions, to the best of my

\footnotetext{
${ }^{24}$ See, e.g., Barker and Hall (1994), Hammer et al. (2005), Johnson and Strange (2007), Hannum et al. (2009), and Nelson (2010).

${ }^{25}$ See, e.g., Dundar and Lewis (1999); Cherednichenko et al. (2004), Roshchina (2004), and Kamyab (2008).
} 
knowledge, so far there were no robust studies that examined national data sets for the purpose of shedding light on spatial disparities in higher education admissions in Georgia, the wider Caucasus, or in post-Soviet settings.

Future studies should replicate the findings regarding the factors of some rural schools' successful performances. For this purpose, exceptionally highachieving as well as low-achieving rural schools should be studied in a comprehensive manner. Achievement levels can be established by using the UNE data sets. Future studies should analyze the school organization characteristics, school leadership, teacher qualifications and approach to teaching and learning, classroom instruction practices, amount of homework and pupil assessment, teacher and pupil expectations, parental involvement with school, engagement with different local and international partners, and school safety and security, among other potentially relevant features. The findings from such studies would help the government plan progressive policy interventions, building on the existing strengths of rural communities. International research shows that small rural communities may have positive characteristics, such as higher teacher morale and better relationships between schools and parents (Baker 2003). New policies could then be designed based on the findings of such studies on rural schools' successful performances.

\section{References}

$\rightarrow$ Ainsworth, James. 2002. "Why Does It Take a Village? The Mediation of Neighborhood Effects on Educational Achievement." Social Forces 81 (1): 117-52.

$\rightarrow$ Andersson, Eva. 2004. "From Valley of Sadness to Hill of Happiness: The Significance of Surroundings for Socioeconomic Career." Urban Studies 41 (3): 64159.

$\rightarrow$ Andersson, Eva, and S. V. Subramanian. 2006. "Explorations of Neighbourhood and Educational Outcomes for Young Swedes." Urban Studies 43 (11): 2013-25.

Baker, Chris. 2003. "Education in Small, Remote and Northern Communities: Challenges to Meet." Education Canada 43 (3): 13-14.

Barker, Bruce, and Robert Hall. 1994. "Distance Education in Rural Schools: Technologies and Practice." Journal of Research in Rural Education 10 (2): 126-28.

BCG Research. 2007. "Education Reform Survey Report.” Unpublished report, BCG Research, Tbilisi.

Brand, Jennie, and Charles Halaby. 2006. "Regression and Matching Estimates of the Effects of Elite College Attendance on Educational and Career Achievement." Social Science Research 35 (3): 749-70.

Brännström, Lars. 2008. "Making Their Mark: The Effects of Neighbourhood and Upper Secondary School on Educational Achievement." European Sociological Review 24 (4): 463-78.

Brasington, David. 2002. "Differences in the Production of Education across Regions and Urban and Rural Areas." Regional Studies 36 (2): 137-45.

Brewer, John, and Albert Hunter. 1989. Multimethod Research: A Synthesis of Styles. Newbury Park, CA: Sage. 
Carnevale, Anthony, and Stephen Rose. 2003. "Socioeconomic Status, Race/Ethnicity, and Selective College Admissions." Report, Century Foundation, New York.

Chankseliani, Maia. 2012. "Mixed-Methods Study of Higher Education Access in Georgia: Does Location Matter?" Doctoral diss., Cambridge University.

Chankseliani, Maia. 2013a. "The Financial Burden of Attending University in Georgia: Implications for Rural Students." Prospects (forthcoming).

Chankseliani, Maia. 2013b. "Higher Education Access in Post-Soviet Georgia: Overcoming a Legacy of Corruption." In Fairness in Access to Higher Education in a Global Perspective: Reconciling Excellence, Efficiency, and Justice, ed. H. D. Meyer, E. P. St. John, M. Chankseliani, and L. Uribe. Rotterdam: SENSE.

Cherednichenko, Galina, Elena Voznesenskaya, and Olga Dymarskaya. 2004. "Accessibility of Education as a Social Problem (Differentiation of Access to Higher Education and Population's Attitude towards It)." Institute of Sociology of the RAS, Moscow. http://www.socpol.ru/research_projects/pdf/004cherednich enko_eng.pdf.

Chevalier, Arnaud, and Gavan Conlon. 2003. "Does It Pay to Attend a Prestigious University?” SSRN eLibrary. http://eprints.lse.ac.uk/19477/1/Does_it_pay_to _attend_a_prestigious_university.pdf.

$\rightarrow$ Clancy, Patrick, and Gaële Goastellec. 2007. "Exploring Access and Equity in Higher Education: Policy and Performance in a Comparative Perspective." Higher Education Quarterly 61 (2): 136-54.

$\rightarrow$ Cortes, Kalena. 2010. "Do Bans on Affirmative Action Hurt Minority Students? Evidence from the Texas Top 10\% Plan." Economics of Education Review 29 (6): 1110-24.

$\rightarrow$ Crane, Jonathan. 1991. "The Epidemic Theory of Ghettos and Neighborhood Effects on Dropping Out and Teenage Childbearing." American Journal of Sociology 96 (5): 1226-59.

Cukrowski, J. 2006. "Central Asia: Spatial Disparities in Poverty." Report, United Nations Development Programme, New York; London School of Economics, London.

Cullen, Julie, Mark Long, and Randall Reback. 2011. "Jockeying for Position: Strategic High School Choice under Texas' Top Ten Percent Plan.” NBER Working Paper no. 16663, National Bureau of Economic Research, Cambridge, MA. http: //www.nber.org/papers/w16663.

Datcher, Linda. 1982. "Effects of Community and Family Background on Achievement." Review of Economics and Statistics 64 (1): 32-41.

$\rightarrow$ Duncan, Greg. 1994. "Families and Neighbors as Sources of Disadvantage in the Schooling Decisions of White and Black Adolescents." American Journal of Education 103 (1): 20-53.

$\rightarrow$ Dundar, Halil, and Darrell Lewis. 1999. "Equity, Quality and Efficiency Effects of Reform in Turkish Higher Education." Higher Education Policy 12:343-66.

EPPM. 2008. "Higher Education Reform-Problems and Perspectives." Bologna Process Template for National Reports: Stocktaking Report, International Institute for Education Policy Planning and Management, Tbilisi.

Foster, Philip. 1977. "Education and Social Differentiation in Less Developed Countries." Comparative Education Review 21 (2-3): 211-29.

$\rightarrow$ Garner, Cathrine, and Stephen Raudenbush. 1991. "Neighborhood Effects on Ed- 
ucational Attainment: A Multilevel Analysis.” Sociology of Education 64 (4): 25162.

GeoStat. 2003. "The Results of the First Population Census of Georgia." Statistical report, National Statistics Office of Georgia, Tbilisi. http://geostat.ge/cms/ site_images/_files/georgian/census/2002/I\%20tomi\%20-\%20saqarTvelos\%20 mosaxleobis \% 202002\%20wlis\%20pirveli\%20erovnuli\%20sayovelTao\%20aR weris $\% 20$ Sedegebi.pdf.

GeoStat. 2009. Statistical Yearbook of Georgia 2009. Tbilisi: National Statistics Office of Georgia.

Gerbing, David, and James Anderson. 1988. "An Updated Paradigm for Scale Development Incorporating Unidimensionality and Its Assessment.” Journal of Marketing Research 25 (2): 186-92.

Government of Georgia. 2007. "Ordinance 246." http://www.government.gov.ge /index.php?lang_id = GEO\&sec_id =95\&info_id $=2534$.

Hammer, Patricia, Georgia Hughes, Carla McClure, Cynthia Reeves, and Dawn Salgado. 2005. "Rural Teacher Recruitment and Retention Practices: A Review of the Research Literature, National Survey of Rural Superintendents, and Case Studies of Programs in Virginia." Charleston, WV: Appalachia Educational Laboratory at Edvantia. http://www.edvantia.org/products/pdf/Rural\%20Recruit ment\% 20Report.pdf.

$\rightarrow$ Hanisch, Kathy, Charles Hulin, and Mary Roznowski. 1998. "The Importance of Individuals' Repertoires of Behaviors: The Scientific Appropriateness of Studying Multiple Behaviors and General Attitudes.” Journal of Organizational Behavior 19 (5): 463-80.

$\rightarrow$ Hannum, Emily, and Meiyan Wang. 2006. "Geography and Educational Inequality in China." China Economic Review 17:253-65.

Hannum, Wallace, Matthew Irvin, Jonathan Banks, and Thomas Farmer. 2009. "Distance Education Use in Rural Schools." Journal of Research in Rural Education 24 (3): 1-15.

Hattie, John. 1985. "Methodology Review: Assessing Unidimensionality of Tests and Itenls." Applied Psychological Measurement 9 (2): 139-64.

$\rightarrow$ Haveman, Robert, and Barbara Wolfe. 1984. "Schooling and Economic Well-Being: The Role of Nonmarket Effects." Journal of Human Resources 19 (3): 377-407.

Helms, Robin. 2008. "University Admission Worldwide." Working Paper no. 15, World Bank, Washington, DC. http://siteresources.worldbank.org/EDU CATION/Resources/278200-1099079877269/547664-1099079956815/EWPS15 _University_Admission_Worldwide.pdf.

Henry, Carla, Manohar Sharma, Cecile Lapenu, and Manfred Zeller. 2003. Microfinance Poverty Assessment Tool. Washington, DC: World Bank.

$\rightarrow$ Heyneman, Stephen P., Kathryn H. Anderson, and Nazym Nuraliyeva. 2008. "The Cost of Corruption in Higher Education." Comparative Education Review 52 (1): $1-25$.

Hulin, Charles. 1991. "Adaptation, Persistence, and Commitment in Organizations." In Handbook of Industrial and Organizational Psychology, ed. Marvin Dunnette and Leaetta Hough. 2nd ed. Palo Alto, CA: Consulting Psychologists Press.

IHEP. 2005. The Investment Payoff: A 50-State Analysis of the Public and Private Benefits 
of Higher Education. Washington, DC: Institute for Higher Education Policy. http: //www.ihep.org/Publications/publications-detail.cfm?id $=43$.

Ivaschenko, Oleksiy, and Aleksandra Posarac. 2008. "Georgia Poverty Assessment." Report no. 4440-GE, World Bank, Washington, DC.

$\rightarrow$ Jacob, James W. 2007. "Social Justice in Chinese Higher Education: Regional Issues of Equity and Access." International Review of Education 52 (1): 149-69.

Jallade, Jean-Pierre. 1978. "Financing Higher Education: The Equity Aspects." Comparative Education Review 22 (2): 309-25.

Janashia, Natia. 2004. "Corruption and Higher Education in Georgia." International Higher Education 34 (Winter): 10-12. http://www.bc.edu/content/dam/files/ research_sites/cihe/pdf/IHEpdfs/ihe34.pdf.

$\rightarrow$ Johns, Gary. 1998. "Aggregation or Aggravation? The Relative Merits of a Broad Withdrawal Construct." Journal of Organizational Behavior 19 (5): 453-62.

Johnson, Jerry, and Marty Strange. 2007. "Why Rural Matters 2007: The Realities of Rural Education Growth." Report, Rural School and Community Trust, Washington, DC. http://files.ruraledu.org/wrm07/WRM07.pdf.

Kamyab, Shahrzad. 2008. "The University Entrance Exam Crisis in Iran." International Higher Education 51:22-23.

Kapur, Devesh, and Megan Crowley. 2008. Beyond the ABCs: Higher Education and Developing Countries. Washington, DC: Center for Global Development. http:// www.cgdev.org/content/publications/detail/15310/.

$\rightarrow$ Konstantinovskiy, David. 2012. "Social Inequality and Access to Higher Education in Russia." European Journal of Education 47 (1): 9-24.

Krugman, Paul. 1995. Development, Geography, and Economic Theory. Cambridge, MA: MIT Press.

Law, James, Sinead Assenti, Gareth Barton, Kirsty McKissock, Deborah Baker, Steve Barrow, and Dan Cookson. 2004. "Community Legal Service: Assessing Need for Legal Advice in Scotland." Technical and graphical report, Scottish Executive Social Research, Edinburgh. http://scotland.gov.uk/Resource/Doc/25954/ 0025032.pdf.

Lee, W. O. 2002. "Equity and Access to Education: Themes, Tensions, and Policies." Manila: Asian Development Bank.

$\rightarrow$ Leventhal, Tama, and Jeanne Brooks-Gunn. 2000. "The Neighborhoods They Live In: The Effects of Neighborhood Residence on Child and Adolescent Outcomes." Psychological Bulletin 126 (2): 309-37.

Liu, Chengfang, Linziu Zhang, Renfu Luo, Xiaobing Wang, Scott Rozelle, Brian Sharbono, Jennifer Adams, Yaojiang Shi, Ai Yue, Hongbin Li, Xiaobing Wang, and Thomas Glauben. 2011. "Early Commitment on Financial Aid and College Decision Making of Poor Students: Evidence from a Randomized Evaluation in Rural China." Economics of Education Review 30 (4): 627-40.

$\rightarrow$ Lloyd, Kim, Kevin Leicht, and Teresa Sullivan. 2008. "Minority College Aspirations, Expectations and Applications under the Texas Top 10\% Law." Social Forces 86 (3): 1105-37.

$\rightarrow$ Long, Mark, Victor Saenz, and Marta Tienda. 2010. "Policy Transparency and College Enrollment: Did the Texas Top Ten Percent Law Broaden Access to the Public Flagships?" Annals of the American Academy of Political and Social Science 627 (1): 82-105. 
Lorentzen, Jochen. 2000. "Georgian Education Sector Study: Higher Education System." Background paper prepared for World Bank, Washington, DC.

$\rightarrow$ Marcenaro-Gutierrez, Oscar, Fernando Galindo-Rueda, and Anna Vignoles. 2007. "Who Actually Goes to University?" Empirical Economics 32 (2-3): 333-57.

Marginson, Simon. 2011. "Equity, Status and Freedom: A Note on Higher Education." Cambridge Journal of Education 41 (1): 23.

Meyer, Heinz-Dieter, Edward P. St. John, Maia Chankseliani, and Lina Uribe, eds. 2013. Fairness in Access to Higher Education in a Global Perspective: Reconciling Excellence, Efficiency, and Justice. Rotterdam: SENSE.

Ministry of Education and Science of Georgia. 2009. "EMIS Data on Secondary Schools and School Graduates." Ministry of Education and Science of Georgia, Tbilisi.

Ministry of Education and Science of Georgia. 2010. "Ordinance 15/n." Ministry of Education and Science of Georgia, Tbilisi. http://www.mes.gov.ge/old/ upload/editor/file/Brdzanebebi/2010/Marti/15k.pdf.

Monks, James. 2000. "The Returns to Individual and College Characteristics: Evidence from the National Longitudinal Survey of Youth." Economics of Education Review 19 (3): 279-89.

Morley, Louise, and Sarah Aynsley. 2007. "Employers, Quality and Standards in Higher Education: Shared Values and Vocabularies or Elitism and Inequalities?" Higher Education Quarterly 61 (3): 229-49.

$\rightarrow$ Morley, Louise, Fiona Leach, and Rosemary Lugg. 2009. "Democratising Higher Education in Ghana and Tanzania: Opportunity Structures and Social Inequalities." International Journal of Educational Development 29 (1): 56-64.

NAEC (National Examinations Center). 2005. The Unified National Examinations 2005. Tbilisi: National Examinations Center.

NAEC (National Examinations Center). 2006a. The Unified National Examinations 2006. Tbilisi: National Examinations Center.

NAEC (National Examinations Center). 2006b. The Unified National Examinations Information Booklet. Tbilisi: National Examinations Center.

NAEC (National Examinations Center). 2007a. The Unified National Examinations 2007. Tbilisi: National Examinations Center.

NAEC (National Examinations Center). 2007b. The Unified National Examinations Information Booklet. Tbilisi: National Examinations Center. http://www.naec.ge/ files /492_Saregistracio-Gazeti-2007.pdf.

NAEC (National Examinations Center). 2008a. The Unified National Examinations 2008. Tbilisi: National Examinations Center.

NAEC (National Examinations Center). 2008b. The Unified National Examinations Information Booklet. Tbilisi: National Examinations Center.

NAEC (National Examinations Center). 2009a. The Unified National Examinations Database. Tbilisi: National Examinations Center.

NAEC (National Examinations Center). 2009b. The Unified National Examinations Information Booklet. Tbilisi: National Examinations Center.

National Center for Education Accreditation. 2006. Annual Report 2006. Tbilisi: National Center for Education Accreditation.

Nelson, Steve. 2010. Leveraging the Unique Features of Small, Rural Schools for Improvement: Lessons Learned. Portland, OR: Education Northwest. 
$\rightarrow$ Ntshoe, Isaac M. 2003. "The Political Economy of Access and Equitable Allocation of Resources to Higher Education." International Journal of Educational Development 23 (4): 381-98.

$\rightarrow$ Oliver, Lisa, James Dunn, Dafna Kohen, and Clyde Hertzman. 2007. "Do Neighbourhoods Influence the Readiness to Learn of Kindergarten Children in Vancouver? A Multilevel Analysis of Neighbourhood Effects." Environment and Planning A 39 (4): 848-68.

Ones, Deniz, and Chockalingam Viswesvaran. 1996. "Bandwidth-Fidelity Dilemma in Personality Measurement for Personnel Selection.” Journal of Organizational Behavior 17 (6): 609-26.

Paunonen, Sampo, Mitchell Rothstein, and Douglas Jackson. 1999. "Narrow Reasoning about the Use of Broad Personality Measures for Personnel Selection." Journal of Organizational Behavior 20 (3): 389-405.

$\rightarrow$ Perna, Laura. 2003. "The Private Benefits of Higher Education: An Examination of the Earnings Premium." Research in Higher Education 44 (4): 451-72.

Rankin, Bruce, and James Quane. 2002. "Social Contexts and Urban Adolescent Outcomes: The Interrelated Effects of Neighborhoods, Families, and Peers on African-American Youth." Social Problems 49 (1): 79-100.

$\rightarrow$ Ranson, Kent, Tara Sinha, Mirai Chatterjee, Akash Acharya, Ami Bhavsar, Saul Morris, and Anne Mills. 2006. "Making Health Insurance Work for the Poor: Learning from the Self-Employed Women's Association's (SEWA) CommunityBased Health Insurance Scheme in India." Social Science and Medicine 62 (3): 70720.

$\rightarrow$ Rephann, Terance. 2002. "The Importance of Geographical Attributes in the Decision to Attend College." Socio-Economic Planning Sciences 36 (4): 291-307.

$\rightarrow$ Rivera, Lauren. 2011. "Ivies, Extracurriculars, and Exclusion: Elite Employers' Use of Educational Credentials." Research in Social Stratification and Mobility 29 (1): 71-90.

Roscigno, Vincent, Donald Tomaskovic-Devey, and Martha Crowley. 2006. "Education and the Inequalities of Place." Social Forces 84 (4): 2121-45.

Roshchina, Yana. 2004. "Study of Higher Education Accessibility Factors." In Accessibility of Higher Education in Russia, ed. S. V. Shishkin. Moscow: Independent Institute for Social Policy.

$\rightarrow$ Roznowski, Mary, and Kathy Hanisch. 1990. "Building Systematic Heterogeneity into Work Attitudes and Behavior Measures." Journal of Vocational Behavior 36 (3): $361-75$.

$\rightarrow$ Sastry, Narayan, Bonnie Ghosh-Dastidar, John Adams, and Anne Pebley. 2006. "The Design of a Multilevel Survey of Children, Families, and Communities: The Los Angeles Family and Neighborhood Survey." Social Science Research 35:1000-1024.

$\rightarrow$ Schneider, Robert, Leaetta Hough, and Marvin Dunnette. 1996. "Broadsided by Broad Traits: How to Sink Science in Five Dimensions or Less." Journal of Organizational Behavior 17 (6): 639-55.

$\rightarrow$ Selvaratnam, Viswanathan. 1988. "Ethnicity, Inequality, and Higher Education in Malaysia." Comparative Education Review 32 (2): 173-96.

Shapiro, Marc, Shiro Nakata, Lela Chakhaia, Eka Zhvania, Giorgi Babunashvili, Nino Pruidze, and Medea Tskhomelidze. 2007. "Evaluation of the Ilia Chavchavadze Program in Reforming and Strengthening Georgia's Schools.” Evaluation 
paper, Padeco, Tokyo. http://www.mes.gov.ge/upload/multi/geo/1209037866 _IC\%20Evaluation\%20Report\%202007\%20Final.pdf.

Social Service Agency. 2009. "Subsidy Recipients' Statistics." http://ssa.gov.ge/ index.php?lang_id $=$ GEO\&sec_id $=610$.

Stransky, Beth, and Annalee Good. 2009. "Addressing Opportunity in Wisconsin's Four-Year Universities: A Comparative Analysis of State College Access Programs." Policy brief, Wisconsin Center for the Advancement of Postsecondary Education, Madison. http://wiscape.wisc.edu/uploads/media/79422a68-5727-4bb2-9d25 -a341c2c08473.pdf.

$\rightarrow$ Sykes, Brooke, and Hans Kuyper. 2009. "Neighbourhood Effects on Youth Educational Achievement in the Netherlands: Can Effects Be Identified and Do They Vary by Student Background Characteristics?" Environment and Planning A 41: 2417-36.

Teacher Professional Development Center. 2008. "Required and Expected Quantities of General School Teachers in Georgia.” Report, Teacher Professional Development Center, Tbilisi.

Temple, Paul. 2006. "Universities without Corruption: A New Approach for Georgia's Higher Education.” International Higher Education 42:19-20.

Tickamyer, Ann, Julie White, Barry Tadlock, and Debra Henderson. 2007. "The Spatial Politics of Public Policy: Devolution, Development, and Welfare Reform." In The Sociology of Spatial Inequality, ed. Linda Lobao, Gregory Hooks, and Ann Tickamyer, 113-39. Albany, NY: SUNY Press.

Tienda, Marta, and Teresa Sullivan. 2010. "The Promise and Peril of the Texas Uniform Admission Law." In The Next Twenty-Five Years: Affirmative Action and Higher Education in the United States and South Africa, ed. David Featherman, Martin Hall, and Marvin Krislov. Ann Arbor: University of Michigan Press.

Transparency International. 2006. "Monitoring the 2006 Unified National Exams in Georgia." Report, Transparency International Georgia, Tbilisi.

UNESCO. 2011. "Revision of the International Standard Classification of Education (ISCED).” http://www.uis.unesco.org/Education/Pages/international-standard -classification-of-education.aspx.

UNICEF. 2001. “A Decade of Transition.” Regional Monitoring Report no. 8, United Nations Children's Fund, Innocenti Research Centre, Florence. http://www .unicef-irc.org/publications/pdf/monee8/eng/4.pdf.

$\rightarrow$ Vinke, Candace, and Stephen Lonergan. 2011. "Social and Environmental Risk Factors for Trachoma: A Mixed Methods Approach in the Kembata Zone of Southern Ethiopia." Canadian Journal of Development Studies 32 (3): 254-68.

Voicu, Bogdan, and Marian Vasile. 2010. "Rural-Urban Inequalities and Expansion of Tertiary Education in Romania." Journal of Social Research and Policy 1 (1): 524.

World Bank. 2009. "Public Spending on Education, Total (\% of GDP)." http:// data.worldbank.org/indicator/SE.XPD.TOTL.GD.ZS.

World Bank. 2012. "Fighting Corruption in Public Services: Chronicling Georgia's Reforms." Report, World Bank, Washington, DC. http://siteresources.world bank.org/GEORGIAEXTN/Resources/9780821394755.pdf.

$\rightarrow$ Zhang, Haifeng, and David Cowen. 2009. "Mapping Academic Achievement and 
Public School Choice under the No Child Left Behind Legislation.” Southeastern Geographer 49 (1): 24-40.

$\rightarrow$ Zhang, Yanhong. 2006. "Urban-Rural Literacy Gaps in Sub-Saharan Africa: The Roles of Socioeconomic Status and School Quality." Comparative Education Review 50 (4): 581-602.

Zimmermann, Randal. 2008. "Equity Considerations in the Access to Higher Education in Central and Eastern Europe." In Education and Social Inequality in the Global Culture, ed. J. Zajda, K. Biraimah, and W. Gaudell. Berlin: Springer. 